\title{
SPORTS AND PERFORMANCE IN THE TRANSGENDER POPULATION: A SYSTEMATIC REVIEW AND META-ANALYSIS
}

SYSTEMATIC REVIEW

REVISÃO SISTEMÁTICA REVISIÓN SISTEMÁTICA

\author{
ESPORTES E DESEMPENHO NA POPULAÇÃO TRANSGÊNERO: UMA REVISÃO SISTEMÁTICA EMETANÁLISE
}

\author{
DEPORTEY RENDIMIENTO EN LA POBLACIÓN TRANSGÉNERO: REVISIÓN SISTEMÁTICA Y METANÁLISIS
}

\author{
Roberto Lohn Nahon' (iD \\ (Physician) \\ Ana Paula Simões da Silva² (D) \\ (Physician) \\ Renan Muniz-Santos ${ }^{3}$ (1) \\ (Student) \\ Rayanne Carneiro Torres de \\ Novaes $^{4}$ (ID \\ (Student) \\ Laura Souza Prado Lobrigati \\ Pedroso ${ }^{5}$ (ID \\ (Student)
}

1. Universidade Federal do Estado do Rio de Janeiro (UNIRIO),

Laboratory of Protein Biochemistry, Rio de Janeiro, RJ, Brazil.

2. Faculdade de Ciências Médicas da Santa Casa de São Paulo, São

Paulo, SP, Brazil.

3. Universidade Federal do Estado do Rio de Janeiro, Rio de Janeiro,

RJ, Brazil.

4. Universidade Federal do Ceará,

Fortaleza, CE, Brazil.

5. Centro Universitário Lusíada, Santos, SP, Brazil.

\section{Correspondence}

Roberto Lohn Nahon

LBP - UNIRIO. Rua Dr. Xavier

Sigaud, 290 - Urca, Rio de

Janeiro, RJ, Brazil. 22290-240.

robertonahon@gmail.com

\begin{abstract}
Introduction: The debate surrounding the regulations on the participation of transgender individuals in sports is not recent, but it is still ongoing. Some sports organizations are more flexible in this regard, while others are more conservative. Objective: Through a systematic review and meta-analysis, this study summarizes the scientific evidence of the effects of cross-sex hormone therapy on muscle strength, hematocrit, and hemoglobin measurements, parameters that seem to be linked to sports performance. Methods: We conducted electronic searches for manuscripts published before November $20^{\text {th }}, 2020$. Studies published in three different databases (PubMed, SciELO, and Lilacs) were included, without any time or language restriction, and using keywords such as "transgender","gender dysphoria","strength","hematocrit", and "hemoglobin". The PRISMA systematization was used for the elaboration of this review, while a meta-analysis was conducted to mathematically evidence the results. The meta-analysis was performed using the random effect model, to find the pooled estimate effect of cross-sex hormone therapy on the parameters analyzed. Results: The electronic search retrieved 21 articles that were eligible for inclusion. Cross-sex hormone therapy influenced the three parameters analyzed in almost all the studies. Overall, there was a significant increase in muscle strength in female-to-males (FtMs), per muscle group analyzed: $+17.7 \%$ (95\% confidence interval [CI]14.9;20.6). In male-to-females (MtFs) the results of the muscle strength analysis were more controversial, but the pooled estimate effect showed a decrease: $-3.6 \%$ (95\% confidence interval [Cl] -6.6; -0.6). Conclusion: Muscle strength, hematocrit, and hemoglobin were altered as a result of cross-sex hormone therapy in both FtMs and MtFs. However, there was a lack of studies comparing the transgender individuals to the population of the same desired gender. Such studies are needed, to better infer rules for the participation of transgender athletes in Olympic sports. Level of Evidence l; Systematic Review and Meta-analysis.
\end{abstract}

Keywords: Sports medicine; Transgender; Athletic performance.

\section{RESUMO}

Introdução: O debate sobre as regulamentações relativas à participação de transgêneros no esporte não é recente, mais ainda está em progresso. Algumas organizações esportivas são mais flexíveis nesse aspecto, enquanto outras são mais conservadoras. Objetivo: Mediante revisão sistemática e metanálise, este estudo resume as evidências científicas dos efeitos do tratamento hormonal de redesignação sexual nas medidas de força muscular, hematócritos e hemoglobina, parâmetros que parecem estar ligados ao desempenho esportivo. Métodos: Foram realizadas buscas eletrônicas de artigos publicados antes de 20 de novembro de 2020 incluídos em três bancos de dados (PubMed, SciELO e Lilacs), sem restrição de tempo ou idioma, sendo usados os descritores "transgender", "gender dysphoria", "strength", "hematocrit" $e$ "hemoglobin". A sistematização PRISMA foi usada para a elaboração desta revisão, enquanto a metanálise foi realizada para evidenciar matematicamente os resultados. A metanálise foi realizada com o modelo de efeito aleatório para encontrar o efeito combinado estimado do tratamento hormonal de redesignação sexual sobre os parâmetros analisados. Resultados: A busca eletrônica recuperou 21 artigos elegiveis. O tratamento hormonal de redesignação sexual influenciou os três parâmetros analisados em quase todos os estudos. No geral, houve um aumento significativo da força muscular nos homens trans (FtMs) no grupo de músculos analisado: $+17,7 \%$ (intervalo de confiança [IC] de 95\% 14,9;20,6). Nas mulheres trans (MtFs) os resultados da análise da força muscular foram mais controversos, mas o efeito de estimativa agrupado mostrou uma diminuição: -3,6\% (intervalo de confiança [IC] de $95 \% 6,6 ;-0,6)$. Conclusão: Força muscular, hematócritos e hemoglobina tiveram niveis alterados em resposta ao tratamento hormonal de redesignação sexual tanto em FtMs quanto em MtFs. No entanto, há escassez de estudos que comparem os indivíduos transgênero com a população do mesmo gênero desejado. Esses estudos são necessários para melhor definir as regras da participação de transgêneros nos esportes olímpicos. Nível de Evidência l; Revisão Sistemática e Metanálise.

Descritores: Medicina do esporte; Transgênero; Desempenho esportivo. 


\section{RESUMEN}

Introducción: El debate sobre las regulaciones relativas a la participación de las personas transgénero en el deporte no es reciente. Algunas organizaciones deportivas son más flexibles, mientras que otras, más conservadoras. Objetivo: Este estudio tuvo como objetivo resumir la evidencia científica sobre los efectos de la terapia hormonal cruzada en la fuerza muscular, hematocrito, y hemoglobina, parámetros que parecen estar vinculados al rendimiento deportivo, mediante revisión sistemática y metanálisis. Métodos: Realizamos búsquedas electrónicas de manuscritos publicados antes del 20 de noviembre de 2020. Se incluyeron estudios publicados en tres bases de datos (PubMed, SciELO y Lilacs) sin restricción de tiempo o lenguaje. Se utilizaron palabras clave como "transgénero", "disforia de género", "fuerza", "hematocrito" y"hemoglobina". Para la elaboración de esta revisión se utilizó la sistematización PRISMA, mientras que se realizó un metanálisis para evidenciar matemáticamente los resultados. El metanálisis se realizó utilizando el modelo de efecto aleatorio, para encontrar el efecto de estimación agrupado de la terapia hormonal cruzada en los parámetros analizados. Resultados: La búsqueda electrónica incluyó 21 artículos. La terapia hormonal cruzada influyó en los tres parámetros analizados en casi todos los estudios. En general, hubo un aumento significativo en la fuerza muscular en hombres trans (FtMs), por grupo muscular analizado: $+17.7 \%$ (95\% intervalo de confianza [CI]14.9;20.6). En mujeres trans (MTFs) los resultados en el análisis de fuerza muscular fueron más controvertidos, pero el efecto de estimación agrupado mostró una disminución:-3.6\% (95\% intervalo de confianza [CI] -6.6; -0.6). Conclusión: Fuerza muscular, hematocrito, y hemoglobina han cambiado sus niveles en respuesta a la terapia hormonal cruzada en hombres trans y mujeres trans. Sin embargo, encontramos una falta de estudios que compararan a las personas transgénero con la población del mismo género deseado, lo que sería necesario para inferir mejor las reglas sobre la participación de los transexuales en los deportes olímpicos. Nivel de Evidencia l; Revisión sistemática y Metanálisis.

Descriptores: Medicina deportiva; Personas Transgénero; Rendimiento atlético.

DOI: http://dx.doi.org/10.1590/1517-8692202127062021_0054

Article received on 03/26/2021 accepted on 06/11/2021

\section{INTRODUCTION}

The universality of sport and its importance as a social and cultural phenomenon places it as the main of pertinent discussions throughout its evolution and place in our society. Main competitions can captivate and inspire several people with the contest among highly trained athletes competing under fair rules. ${ }^{1,2}$ However, fairness is a subjective concept with malleable limits that may change over time; often following social needing and scientific questions. ${ }^{3}$

Sex can be defined as an objective, specific biological state, notably genetic, chromosomal, gonadal, hormonal, and phenotypic (including genital) sex, each of which has a characteristic form ${ }^{4}$. Disorders of sex development are understood as a large group of congenital conditions that affect human sex determination and/or differentiation, for example, Klinefelter Syndrome. ${ }^{4,5}$ On the other hand, gender is a subjective, malleable, self-identified social construct that defines a person's gender role and orientation. ${ }^{6}$ Until 2018 there was a medical classification for a cross-gender identification, known as gender dysphoria. ${ }^{6}$ Nowadays, since the World Health Assembly approved the International Statistical Classification of Diseases and Related Health Problems-11 (ICD-11) in 2019, be transgender is no longer classified as a mental disorder. The transgender nomenclature was sustained, as a transgender man (FtMs) for an individual with female sex designated at birth who identifies himself with male gender identity and a transgender woman (MtFs) for an individual with male sex at birth who identifies herself with female gender identity. ${ }^{6-9}$

The fact that an individual identified himself (or herself) as transgender does not implicate that he (or she) wants medical attention or treatment. However, from a medical perspective, hormonal, like Cross-Sex Hormone Therapy (CSHT), and surgical treatments are usually related to the phenotypic characteristics of the desired genus. These treatments, similarly to others in medicine, contain secondary effects, risks and, ideally, must have multidisciplinary monitoring. ${ }^{10,11}$

In most competitive sports, we find two categories: male and female. Its classification seemed coherent, given that, for example, the male results in the 100 meters, swimming, and weightlifting, has significantly better performance values than that of women. ${ }^{12-14}$ Some phenotypic characteristics, such as height, can be easily identified. ${ }^{15}$ In part, these and other differences between men and women can be explained by the fact that, after puberty, men produce 20 times more testosterone than women. ${ }^{16,17}$ There are some sports where this striking post-pubertal can provide men performance advantage by increasing circulating testosterone, muscle mass, muscle strength, and higher hemoglobin levels, like weightlifting and marathon, respectively. ${ }^{18}$ Thus, this rule did not plan space for MtFs, for example, which could, on the one hand, have a competitive disadvantage with the category of origin and, on the other, have an undue advantage concerning the category of destination, or in the case of the FtMs the opposite. ${ }^{19}$

In October 2003, the International Olympic Committee (IOC) Medical Commission stated the first policy for inclusion of transgender athletes in the Olympic Games, the Stockholm Consensus. This consensus allowed MtFs who had undergone cross-sex hormone therapy before puberty to compete in the female category and FtMs who had transitioned before puberty to compete in the male category. ${ }^{19}$ The International Association of Athletic Federations (IAAF) declared, in 2011, endorsed by the IOC in 2012, a rule for hyperandrogenic women. In 2015, The IOC stated that FtMs are allowed to compete in the male category without restrictions, while MtFs must have testosterone levels below $10 \mathrm{nmol} / \mathrm{L}$ for at least 12 months before the competition..$^{20-22}$ As an example of the dynamism of this theme, the very IAAF in turn recently, in 2019, stated that the testosterone levels should be below $5 \mathrm{nmol} / \mathrm{L}$ for 12 months and that their expert medical panel shall make a comprehensive review of the athlete's care and medical treatment following sex reassignment. ${ }^{23}$

It is broadly understood that in elite sports competition, physical capacity is an important asset for the athlete's performance and, consequently, for your achievements and spotlight. ${ }^{24}$ However, there is no essential data on the magnitude of change in performance indicators with CSHT.

Understand the effect on the competition when a transgender person is competing in a specific sport is a delicate question that, until nowadays, has no answer that can ensure fair, safe, and meaningful competition while, at the same time, can protect transgender individual's rights to participate in a universal inclusion of the sport. ${ }^{25,26}$ In this context, this review may be useful to assist in the evolution of the criteria 
that determine the participation of transgender athletes in elite sport. Therefore, the objective of the present review study was to research the influence of CSHT on physical capacity and, consequently, on the performance of the athletes.

\section{METHODS}

We analyzed a total of 795 articles retrieved from three different databases: PubMed, SciELO, and Lilacs. Five studies were collected from the references on that studies.

\section{Study search and selection strategy}

After discussion with a team of orthopedists, psychiatrists, sports doctors, physiotherapists, psychologists, and medical students, the search was performed using the following terms: Transgender, Transsexual, Strength, Force, Power, Sport, Performance, Endurance, Muscle, Physiology, Complete blood count, Full blood count, and Hemoglobin. The search selected manuscripts published prior to November $20^{\text {th }}, 2020$. Also, the authors performed a manual search in the references of included studies.

\section{Inclusion and exclusion criteria}

We included studies that: 1) used a prospective or retrospective approach and showed pre-and post-therapy values or absolute or relative changes 2) evaluated the effects of the cross-sex hormone therapy on strength, or hemoglobin or hematocrit measurements. We do not consider in this review: guidelines, case reports, comments, editorials, letters to the editor. Regarding the subjects, we consider transgenders male-to-female (MtFs) and female-to-male (FtMs). No limitation in age; the level of sports performance; the date of publication; or the language in which the article was written. We included only studies with healthy participants free of acute or chronic diseases.

\section{Data extraction}

The data extraction included: 1) general characteristics of the study (authors, year of publication, and country), 2) data on the study population (sample size, transgender male to female, transgender female to male and age), 3) the method for assessing muscle strength, 4) drugs used in the therapy and 5) means and standard deviations of pre-and post-measurements or absolute or relative change scores. We contacted the correspondent author in case of any missing information.

\section{Risk of bias assessment}

The articles' quality was analyzed using the PEDro scale15, which was used in similar studies. This scale consists of analyzing, through 11 items, two characteristics related to the articles' quality, the internal validity, and if the paper presents enough statistical information that makes itself comprehensible. Scale scores range from 0 to 10 (the first item on the list is not counted), and studies with a score greater than five are considered high quality. We analyzed the risk of bias using the following criteria: Random sequence generation (selection bias), Allocation concealment (selection bias), Blinding of participants and personnel (performance bias), Blinding of outcomes assessment (detection bias), and Selective reporting (reporting bias). Two independent authors simultaneously analyzed the risk of bias assessment results.

\section{Statistical Analysis}

The analyses of pooled data to calculate the effect sizes were performed with a random-effects model, and the data were reported as means difference with a 95\% confidence interval. Change scores were calculated as the means differences percentage between pre- and post-measurements. Only studies that showed the results in terms of mean $+\mathrm{Sd}$ were included in the meta-analysis. Regarding strength measurements, if an article has measured more than one muscle group strength, we considered each finding separately for the analysis.

\section{RESULTS}

We found a total of 795 articles from three different databases (PubMed, SciELO, Lilacs), applying the extraction criteria. After an abstract and/or full-text screening, a total of 21 articles (2.6\%) were eligible for the analyses, considering the inclusion criteria. (Figure 1) Among the 21 articles, five of them (23.8\%) analyzed the effects of cross-sex hormone therapy on muscle strength measures, and 17 (80.9\%) analyzed the effects on hemoglobin and/or hematocrit levels, as shown in Table 1.

\section{Participants and drugs}

A total of 533 MtFs and 963 FtMs participated in the included studies. The treatment of MtFs consisted of cyproterone acetate (cpa), or spironolactone, or gonadotropin-releasing hormone (GnRHa) antagonist alone or in combination with transdermal estradiol (patch

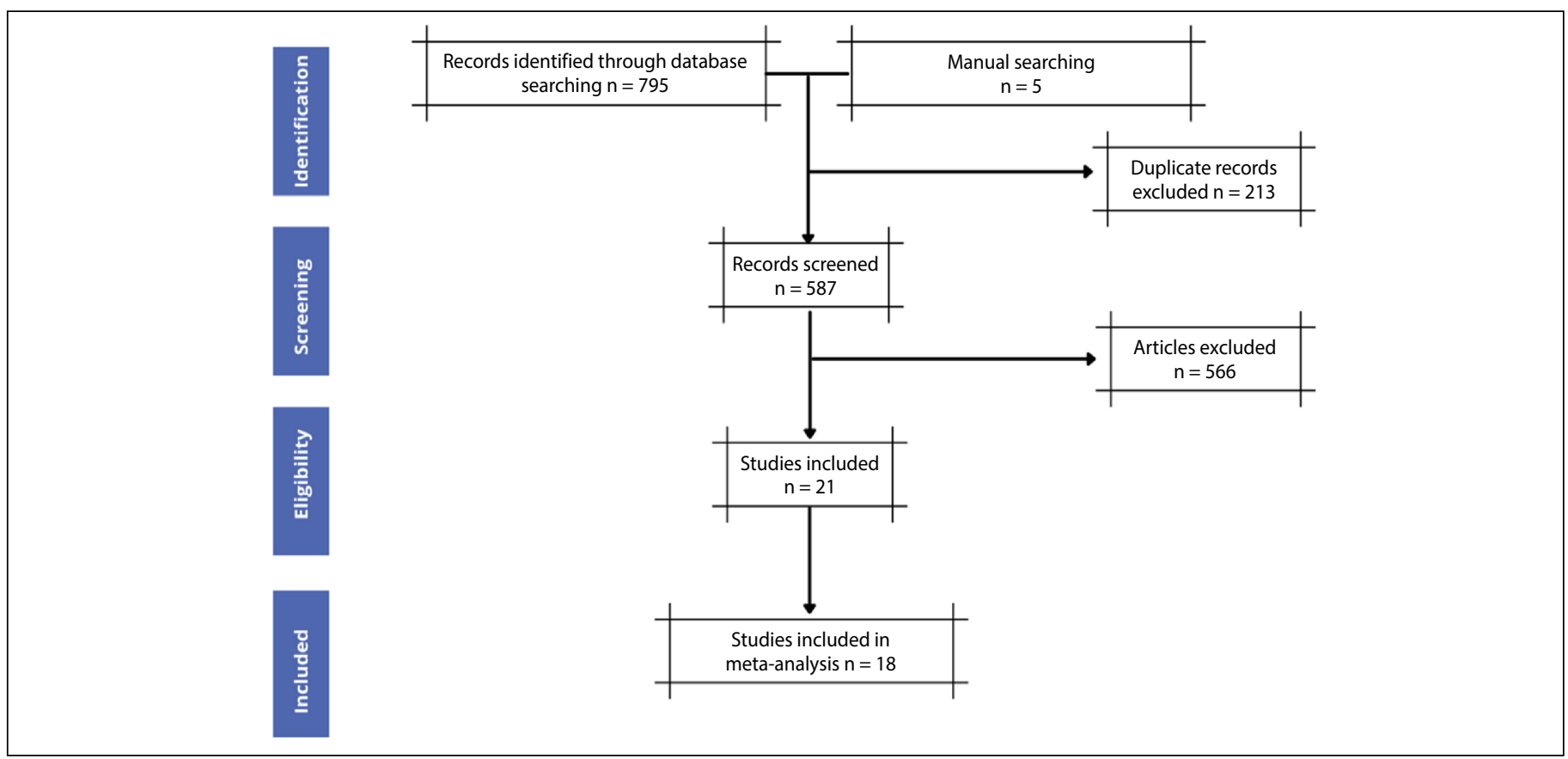

Figure 1. Article selection flowchart. 
Table 1: Data extraction of included studies.

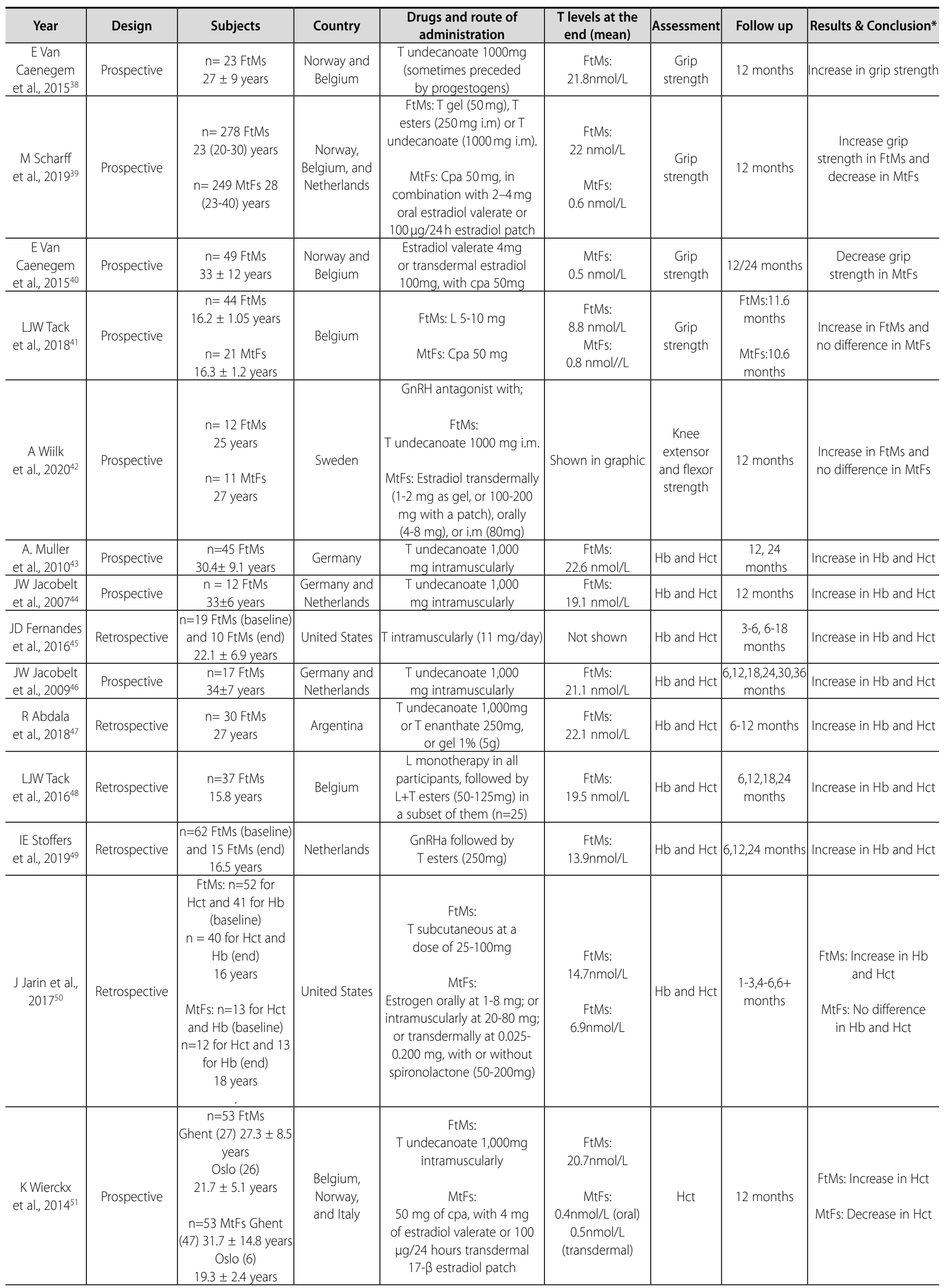




\begin{tabular}{|c|c|c|c|c|c|c|c|c|}
\hline $\begin{array}{l}\text { J Olson- } \\
\text { Kennedy } \\
\text { et al., } 2018^{52}\end{array}$ & Prospective & $\begin{array}{c}\mathrm{n}=34 \mathrm{FtMs} \\
18 \text { years }\end{array}$ & United States & \begin{tabular}{|c|} 
FtMs: \\
T cypionate via subcutaneous. \\
Two were on simultaneous \\
GnRHa \\
MtFs: \\
$17 \beta$ estradiol (orally \\
$1-6 \mathrm{mg}$, or injectable 20- \\
30mg) with or without \\
spironolactone (100-200 \\
mg orally) or a GnRH analog, \\
and in some cases, the \\
addition of progesterone. \\
\end{tabular} & $\begin{array}{c}\text { FtMs } \\
18.5 \mathrm{nmol} / \mathrm{L} \\
\mathrm{MtFs} \\
5.9 \mathrm{nmol} / \mathrm{L}\end{array}$ & $\mathrm{Hb}$ & 24 months & $\begin{array}{l}\text { FtMs: Increase in } \mathrm{Hb} \\
\text { MtFs: Decrease in } \mathrm{Hb}\end{array}$ \\
\hline $\begin{array}{l}\text { JA SoRelle } \\
\text { et al.,201853 }\end{array}$ & Retrospective & \begin{tabular}{|c}
$\mathrm{n}=56$ FtMs (baseline) \\
$\mathrm{n}=81$ for $\mathrm{Hb}$ and \\
80 for $\mathrm{Hct}$ (end) \\
30 years \\
\\
$\mathrm{n}=73 \mathrm{MtFs}$ (baseline) \\
$\mathrm{n}=105$ for Hb and \\
Hct(end) \\
33 years \\
\end{tabular} & United States & $\begin{array}{l}\text { FtMs: T injections, ranging } \\
\text { from } 35 \text { to } 300 \text { mg } \\
\text { MtFs: Oral estradiol 2-8 } \\
\text { mg, with or without } \\
\text { spironolactone }\end{array}$ & $\begin{array}{c}\text { FtMs: } \\
\text { 22.3nmol/L } \\
\text { MtFs: } \\
1.9 \mathrm{nmol} / \mathrm{L}\end{array}$ & $\mathrm{Hb}$ and $\mathrm{Hct}$ & $6+$ months & $\begin{array}{l}\text { FtMs: Increase in } \mathrm{Hb} \\
\text { and } \mathrm{Hct} \\
\text { MtFs: Decrease } \\
\text { in } \mathrm{Hb} \text { and } \mathrm{Hct}\end{array}$ \\
\hline $\begin{array}{l}\text { R Vita et al., } \\
2018^{10}\end{array}$ & Retrospective & $\begin{array}{c}n=11 \text { FtMs } \\
25.1+3.7 \text { years } \\
n=21 \mathrm{MtFs} \\
25.2+7 \text { years }\end{array}$ & Italy & $\begin{array}{l}\text { FtMs: T enanthate or } \\
\text { undecanoate } \\
\text { MtFs: Estradiol valerate } \\
\text { (2-6 mg/d) with or without } \\
\text { cpa (50-100 mg/d). Three } \\
\text { patients took progesterone. }\end{array}$ & $\begin{array}{l}\text { FtMs: } \\
17 \mathrm{nmol} / \mathrm{L} \\
\text { MtFs: } \\
1.1 \mathrm{nmol} / \mathrm{L}\end{array}$ & $\mathrm{Hb}$ and $\mathrm{Hct}$ & $\begin{array}{l}30 \text { months } \\
\text { (mean) }\end{array}$ & $\begin{array}{c}\text { FtMs: Increase in } \mathrm{Hb} \\
\text { and } \mathrm{Hct} \\
\text { MtFs: Decrease } \\
\text { in } \mathrm{Hb} \text { and Hct }\end{array}$ \\
\hline $\begin{array}{l}\text { A Wiik } \\
\text { et al., } 2020^{42}\end{array}$ & Prospective & $\begin{array}{l}\mathrm{n}=12 \text { FtMs } \\
] 25+5 \text { years } \\
\mathrm{n}=11 \mathrm{MtFs} \\
27+4 \text { years }\end{array}$ & Sweden & $\begin{array}{c}\text { GnRH antagonist with; } \\
\text { FtMs: } \\
\text { T undecanoate } 1000 \text { mg i.m.; } \\
\text { MtFs: } \\
\text { estradiol transdermally } \\
\text { (1-2 mg as gel, or 100-200 } \\
\text { mg with a patch), orally } \\
\text { (4-8 mg), or i.m (80mg) }\end{array}$ & Shown in graphic & $\mathrm{Hb}$ & 12 months & $\begin{array}{l}\text { FtMs: Increase in } \mathrm{Hb} \\
\text { MtFs: Decrease in } \mathrm{Hb}\end{array}$ \\
\hline $\begin{array}{l}\text { A Mueller } \\
\text { et al., } 2007^{54}\end{array}$ & Prospective & $\begin{array}{c}\mathrm{n}=35 \mathrm{FtMs} \\
29.6+8.9 \text { years }\end{array}$ & Germany & $\begin{array}{l}\text { Tundecanoate } 1,000 \\
\text { mg intramuscularly }\end{array}$ & $\begin{array}{c}\text { FtMs: } \\
27.5 \mathrm{nmol} / \mathrm{L}\end{array}$ & $\mathrm{Hb}$ and $\mathrm{Hct}$ & 12 months & Increase in $\mathrm{Hb}$ and $\mathrm{Hct}$ \\
\hline $\begin{array}{l}\text { P Chandra } \\
\text { et al., } 2010^{55}\end{array}$ & Prospective & $\begin{array}{l}\mathrm{n}=12 \text { FtMs } \\
29+9 \text { years }\end{array}$ & United States & $\begin{array}{l}\text { T esters, cypionate } \\
\text { or enanthate }\end{array}$ & \begin{tabular}{|c|} 
FtMs: \\
$34.6 \mathrm{nmol} / \mathrm{L}$ \\
\end{tabular} & $\mathrm{Hct}$ & 12 months & Increase in Hct \\
\hline $\begin{array}{l}\text { C. Pelusi } \\
\text { et al., } 2014^{56}\end{array}$ & Prospective & $\begin{array}{l}n=45 \text { FtMs } \\
23.5 \text { years }\end{array}$ & Italy & $\begin{array}{l}\text { T gel, or undecanoate } \\
\text { or esters }\end{array}$ & \begin{tabular}{|c|} 
FtMs: \\
$20.5 \mathrm{nmol} / \mathrm{L}$ (gel); \\
$25.7 \mathrm{nmol} / \mathrm{L}$ (esters); \\
$21.3 \mathrm{nmol} / \mathrm{L}$ \\
(undecanoate) \\
\end{tabular} & $\mathrm{Hb}$ and $\mathrm{Hct}$ & 12 months & Increase in $\mathrm{Hb}$ and $\mathrm{Hct}$ \\
\hline $\begin{array}{l}\text { Uw Tack } \\
\text { et al., } 2017^{57}\end{array}$ & Retrospective & $\begin{array}{l}n=27 \text { MtFs } \\
16.5 \text { years }\end{array}$ & Belgium & $\begin{array}{l}\text { Cpa (50mg) monotherapy for } \\
\text { at least } 6 \text { months, and then } \\
\text { incremental doses of estrogen }\end{array}$ & $\begin{array}{c}\text { MtFs: } \\
5.82 \mathrm{nmol} / \mathrm{L}\end{array}$ & $\mathrm{Hb}$ and $\mathrm{Hct}$ & 24 months & Decrease in $\mathrm{Hb}$ and $\mathrm{Hct}$ \\
\hline
\end{tabular}

or gel), or oral (estradiol valerate), or intramuscular (estrogenpolyphosphate). FtMs used testosterone ( $T$ ) undecanoate, T cypionate, T esters, T gel, T patch, or lynestrenol (L). In a few studies, trans men also used GnRHa or progestins.

\section{Changes in strength measurements}

We found a total of five studies concerning the effects of cross-sex hormone therapy on strength measurements, four of them (80\%) in MtFs and four (80\%) in FtMs. Among these studies, one of them (20\%) measured lower limb muscle strength (knee extensor and flexor strength), and four studies (80\%) measured grip strength, as shown in Table 1.

All studies in FtMs showed an increase in strength, and the average increase was $16,4 \pm 5.0 \%$ per muscle group analyzed. The pooled estimate effect of strength measurements changes at the end of the researches was $+17.73 \%$ (95\% confidence interval [CI]14.9;20.6). (Figure 2)

From four studies in MtFs, two of them (50\%) showed no difference between post-therapy and pre-therapy measurements, but in one of these studies (LJW Tack - 2018), an increase in strength measurements was expected, due to the age of the participants, therefore the result could be interpreted as a decrease in strength levels. The pooled estimate effect of strength measurements changes at the end of the researches was -3.63\% (95\% confidence interval [Cl] -6.6; -0.6). (Figure 3) Among the two studies (50\%) that showed a decrease in strength measurements, the average decrease was $6.9 \pm 3.7 \%$.

\section{Changes in hemoglobin and hematocrit levels}

Among the 17 articles concerning the effects of cross-sex hormone therapy on hemoglobin and/or hematocrit levels, we found seven studies (41.2\%) in MtFs, six (35.3\%) for hemoglobin, and five (29.4\%) for hematocrit analysis. From these 17 articles, we also found 16 studies $(94,1 \%)$ in FtMs, 14 (82.4\%) studies for hemoglobin, and 13 (76.5\%) for hematocrit analysis, as shown in Table 1. Five of six studies in MtFs (83.3\%) showed a decrease, while one study $(16,7 \%)$ showed no difference in hemoglobin levels from baseline. Among studies that showed a decrease in hemoglobin levels, the average decrease was $9 \pm 1 \%(-1.24$ to $-1.57 \mathrm{~g} / \mathrm{dL})$. Also, four of the five studies (80\%) in MtFs showed a decrease, while one (20\%) showed no difference in hematocrit measurement, and the average decrease was $8.2 \pm 1.4 \%$ (3.2 to 4.7\%). The pooled estimate effect of hemoglobin and hematocrit changes at the end of the researches was $-1.34 \mathrm{~g} / \mathrm{dL}$ (95\% confidence interval [Cl] -1.59; -1.10) and -3.62\% (95\% confidence interval [Cl] -4.23; -3.02). (Figure 4 and 5) 


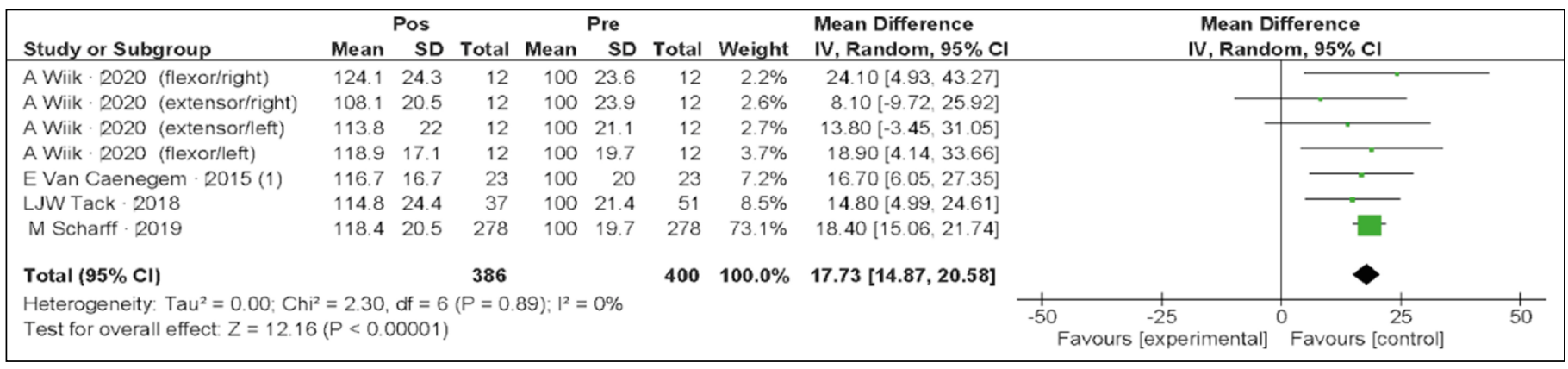

Figure 2. Strength measurements in FtMs (approximately 12 months on CSHT).

\begin{tabular}{|c|c|c|c|c|c|c|c|c|c|c|c|c|c|c|}
\hline \multirow[b]{2}{*}{ Study or Subgroup } & \multicolumn{3}{|c|}{ Pos } & \multicolumn{3}{|c|}{ Pre } & \multirow{2}{*}{\multicolumn{2}{|c|}{$\begin{array}{l}\text { Mean Difference } \\
\text { IV, Random, } 95 \% \mathrm{Cl}\end{array}$}} & \multirow{2}{*}{\multicolumn{6}{|c|}{$\begin{array}{c}\text { Mean Difference } \\
\text { IV, Random, } 95 \% \mathrm{CI}\end{array}$}} \\
\hline & Mean & SD & Total & Mean & SD & Total & & & & & & & & \\
\hline A Wiik 2020 (flexor/left) & 99.2 & 20.3 & 11 & 100 & 21 & 11 & $3.0 \%$ & $-0.80[-18.06,16.46]$ & & & & & & \\
\hline A Wiik 2020 (extensor/right) & 103.4 & 18.4 & 11 & 100 & 19.9 & 11 & $3.5 \%$ & $3.40[-12.62,19.42]$ & & & & & & \\
\hline A Wiik 2020 (extensor/left) & 99.1 & 18 & 11 & 100 & 18.9 & 11 & $3.8 \%$ & $-0.90[-16.32,14.52]$ & & & & & & \\
\hline A Wiik 2020 (flexor/right) & 104.6 & 15.3 & 11 & 100 & 15.3 & 11 & $5.5 \%$ & $4.60[-8.19,17.39]$ & & & & & & \\
\hline LJW Tack 2018 & 96 & 14.4 & 18 & 100 & 22.1 & 21 & $6.8 \%$ & $-4.00[-15.56,7.56]$ & & & & & & \\
\hline E Van Caenegem · 2015 (2) & 92.9 & 20.9 & 44 & 100 & 20.9 & 49 & $12.5 \%$ & $-7.10[-15.61,1.41]$ & & & & & & \\
\hline M Scharff $\cdot 2019$ & 95.7 & 21.3 & 249 & 100 & 21.3 & 249 & $64.8 \%$ & $-4.30[-8.04,-0.56]$ & & & -7 & & & \\
\hline Total $(95 \% \mathrm{Cl})$ & & & 355 & & & 363 & $100.0 \%$ & $-3.63[-6.64,-0.62]$ & & & & & & \\
\hline \multicolumn{6}{|c|}{$\begin{array}{l}\text { Heterogeneity: } \text { Tau }^{2}=0.00 ; \mathrm{Ch}^{2}=3.32, \mathrm{df}=6(\mathrm{P}=0.77) ;\left.\right|^{2}=0 \% \\
\text { Test for overall effect: } Z=2.36(P=0.02)\end{array}$} & & & & $\stackrel{\longmapsto}{-50}$ & $\begin{array}{l}-25 \\
1 \mathrm{exp}\end{array}$ & ${ }_{\text {erimental] }}^{0}$ & Favours [c & $\begin{array}{l}1 \\
25 \\
\text { ontrol] }\end{array}$ & 50 \\
\hline
\end{tabular}

Figure 3. Strength measurements in MtFs (approximately 12 months on CSHT).

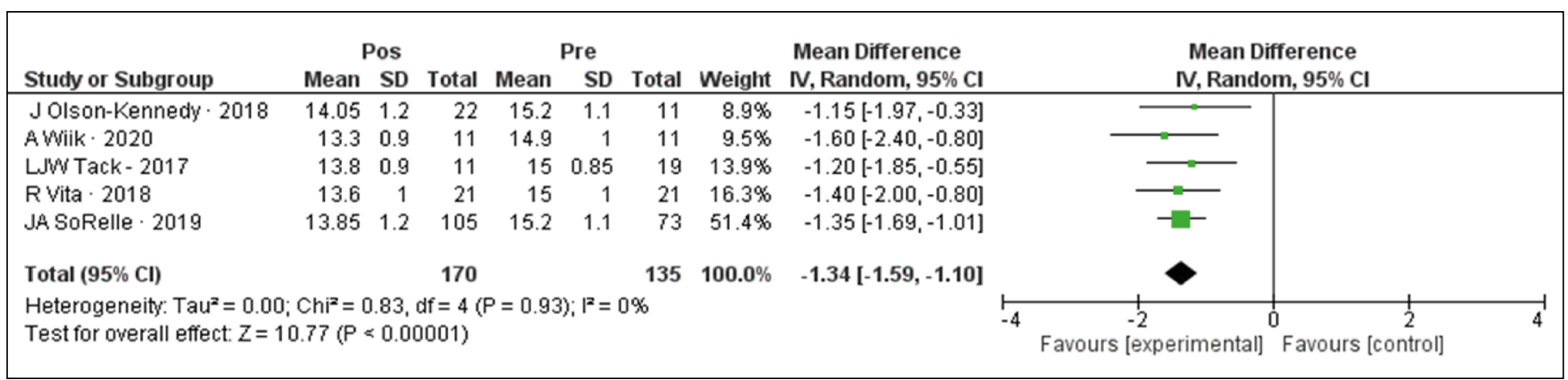

Figure 4. Hemoglobin levels at the end of the studies in MtFs, all measurements beyond six months.

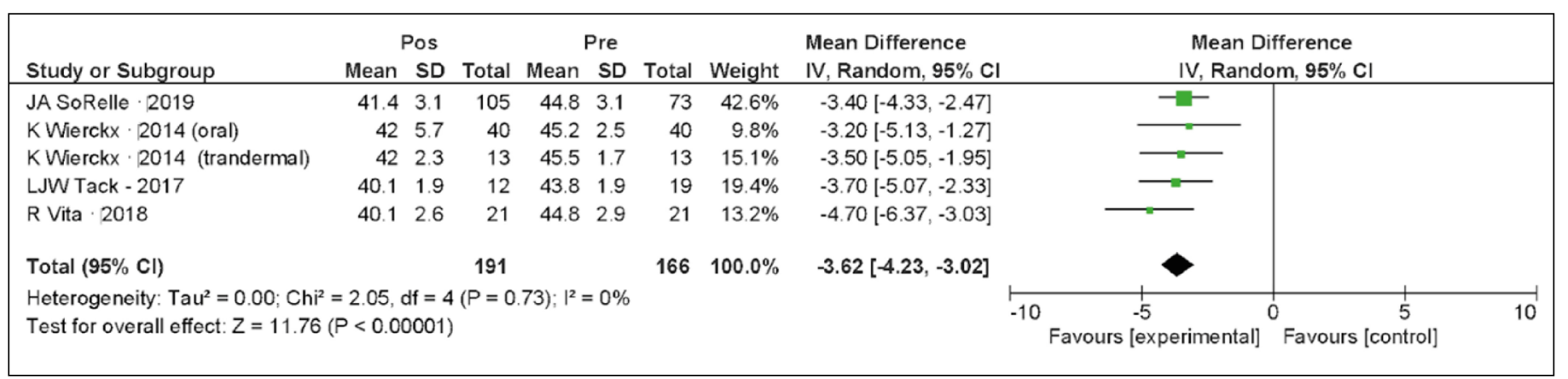

Figure 5. Hematocrit levels at the end of the studies in MtFs, all measurements beyond six months.

All studies in FtMs showed an increase in hemoglobin and hematocrit levels, and the average increase at the end of the researches was $12.2 \pm 3.7 \%$ ( 0.4 to $2.5 \mathrm{~g} / \mathrm{dL}$ ) and $11.35 \pm 3.2 \%$ (3.3 to $6.9 \%)$, respectively. The pooled estimate effect of hemoglobin changes at the end of the researches was $+1.83 \mathrm{~g} / \mathrm{dL}$ (95\% confidence interval $[\mathrm{Cl}] 1.56 ; 2.11)$ (Figure 6), and when it comes to hematocrit changes, the pooled estimate effect was $+4.82 \%$ (95\% confidence interval [CI] 3.99;5.65). (Figure 7) After only 12 months of CSHT in FtMs, the pooled estimate effect on hemoglobin and hematocrit were $+1.37 \mathrm{~g} / \mathrm{dL}$ (95\% confidence interval $[\mathrm{Cl}] 1.08 ; 2.11)$ and $+4.13 \%$ (95\% confidence interval [CI] 3.09;5.17). (Figure 8 and 9)

\section{DISCUSSION}

After systematic review and meta-analysis, focused on the effects of CSHT on strength measurements (grip, knee flexor, and knee extensor) and hematocrit/hemoglobin levels in FtMS and MtFs, we found a significant difference in these measurements with $T$ administration or suppression. T administration (FtMs) was correlated with an increasing strength, hemoglobin, and hematocrit measurements, while T suppression (MtFs) was correlated with a decrease. Agreeing that the T deprivation could reverse the previous effect of its exposure in muscle strength, ${ }^{27}$ while T administration can increase these parameters, ${ }^{28}$ and they seem to be linked to sports performance, ${ }^{18}$ as described below. 


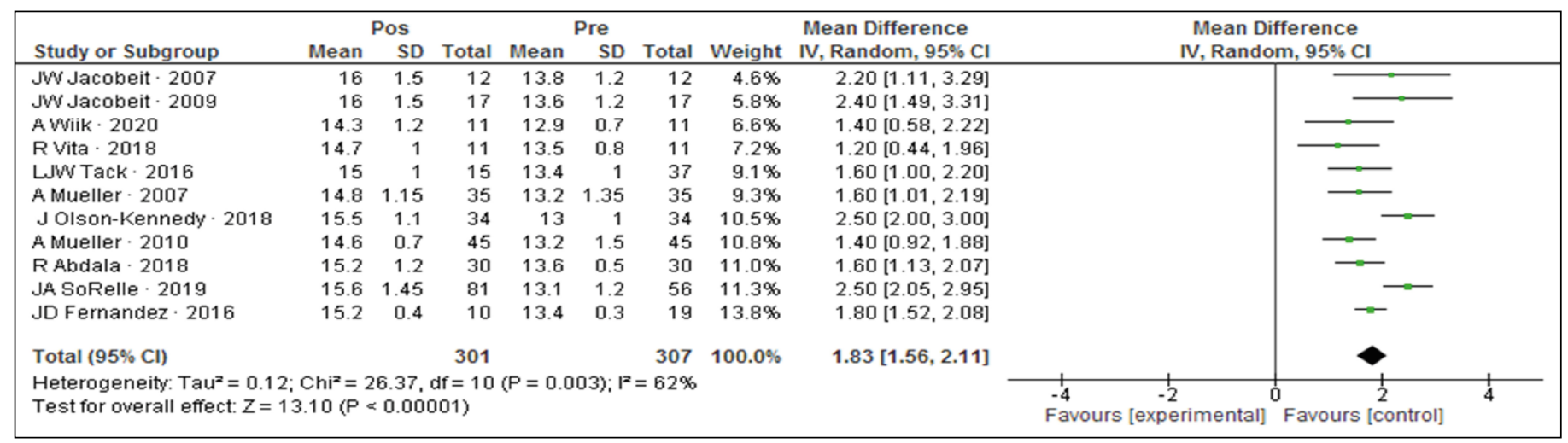

Figure 6. Hemoglobin levels at the end of the studies in FtMs, all measurements beyond six months.

\begin{tabular}{|c|c|c|c|c|c|c|c|c|c|c|c|}
\hline Study or Subgroup & \multicolumn{3}{|c|}{ Pos } & \multicolumn{3}{|c|}{ Pre } & \multicolumn{2}{|r|}{ Mean Difference } & \multicolumn{3}{|c|}{$\begin{array}{c}\text { Mean Difference } \\
\text { IV, Random, } 95 \% \mathrm{Cl}\end{array}$} \\
\hline JW Jacobeit · 2009 & 46 & 4 & 17 & 41 & 4 & 17 & $6.1 \%$ & $5.00[2.31,7.69]$ & & & \\
\hline R vita $\cdot 2018$ & 43.5 & 3.1 & 11 & 40 & 2.9 & 11 & $6.7 \%$ & $3.50[0.99,6.01]$ & & & \\
\hline A Mueller $\cdot 2007$ & 46.25 & 3.35 & 35 & 41.5 & 3.3 & 35 & $10.7 \%$ & $4.75[3.19,6.31]$ & & & \\
\hline A Mueller 2010 & 44.7 & 3.7 & 45 & 41.2 & 3.2 & 45 & $11.3 \%$ & $3.50[2.07,4.93]$ & & & \\
\hline LJW Tack· 2016 & 43.8 & 2.1 & 15 & 39.95 & 2.4 & 36 & $11.9 \%$ & $3.85[2.53,5.17]$ & & & \\
\hline JA SoRelle $\cdot 2019$ & 46.7 & 3.7 & 80 & 39.8 & 3.3 & 56 & $12.7 \%$ & $6.90[5.71,8.09]$ & & & \\
\hline \multirow{2}{*}{\multicolumn{8}{|c|}{$\begin{array}{l}\text { Heterogeneity: } \text { Tau }^{2}=1.05 ; \mathrm{Chi}^{2}=26.04, \mathrm{df}=9(\mathrm{P}=0.002) ; \mathrm{I}^{2}=65 \% \\
\text { Test for overall effect: } Z=11.40(P<0.00001)\end{array}$}} & $4.82[3.99,5.65]$ & & & \\
\hline & & & & & & & & & \begin{tabular}{lcc} 
& \multicolumn{1}{c}{$c$} \\
-10 & -5 & 1 \\
& Favours [experimental]
\end{tabular} & Favours & $\begin{array}{l}5 \\
5 \\
\text { ontrol] }\end{array}$ \\
\hline
\end{tabular}

Figure 7. Hematocrit levels at the end of the studies in FtMs, all measurements beyond six months.

\begin{tabular}{|c|c|c|c|c|c|c|c|c|c|c|}
\hline \multirow[b]{2}{*}{ Study or Subgroup } & \multicolumn{3}{|c|}{ Pos } & \multicolumn{3}{|c|}{ Pre } & \multirow{2}{*}{\multicolumn{2}{|c|}{$\begin{array}{cl} & \text { Mean Difference } \\
\text { Weight } & \text { IV, Random, } 95 \% \mathrm{Cl}\end{array}$}} & \multirow{2}{*}{\multicolumn{2}{|c|}{$\begin{array}{c}\text { Mean Difference } \\
\text { IV, Random, } 95 \% \mathrm{Cl}\end{array}$}} \\
\hline & Mean & SD & Total & Mean & SD & Total & & & & \\
\hline A Wiik $\cdot 2020$ & 14.3 & 1.2 & 12 & 12.9 & 0.7 & 12 & $10.0 \%$ & $1.40[0.61,2.19]$ & & \\
\hline JW Jacobeit $\cdot 2007$ & 15.1 & 0.7 & 12 & 13.8 & 1.2 & 12 & $10.0 \%$ & $1.30[0.51,2.09]$ & & \\
\hline A Mueller · 2010 & 14.8 & 1.1 & 45 & 13.2 & 1.5 & 45 & $16.8 \%$ & $1.60[1.06,2.14]$ & & \\
\hline LJW Tack 2016 & 14.1 & 0.9 & 20 & 13.4 & 1 & 37 & $18.2 \%$ & $0.70[0.19,1.21]$ & & $\longrightarrow$ \\
\hline R Abdala - 2018 & 15.2 & 1.2 & 30 & 13.6 & 0.5 & 30 & $20.2 \%$ & $1.60[1.13,2.07]$ & & - \\
\hline
\end{tabular}

Figure 8. Hemoglobin levels at 12 months in FtMs.

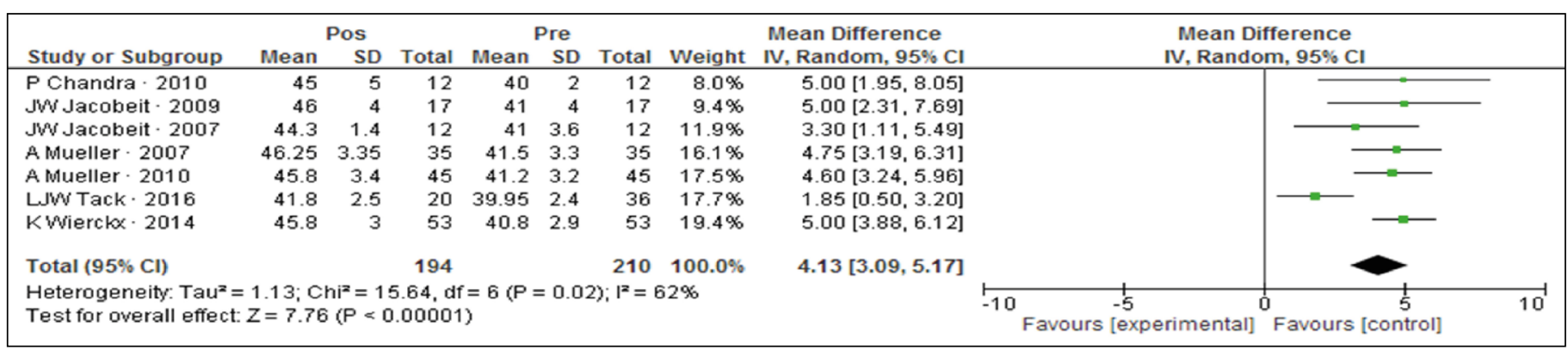

Figure 9. Hematocrit levels at 12 months in FtMs.

\section{Strength}

The testosterone's role in muscle tissue is widely studied, and its action stimulating an increase in muscle protein synthesis ${ }^{29}$ and muscle strength has also been described. Strength can improve athletic performance in some sports, like weightlifting, and track and field events. ${ }^{30}$

In our review, all studies in FtMs showed an increase in muscle strength measurements post-therapy, and consequently, the meta-analysis showed an increase in the pooled estimate effect. This finding agrees with a meta-analysis that analyzed the effects of testosterone replacement therapy in elderly men, using only double-randomized trials, and found an increase in muscle strength, ${ }^{31}$ while one clinical review paper ${ }^{32}$ note that previous studies "show androgen replacement in older men increases muscle and reduces fat mass to a small degree, but to date has not improved muscle strength...

When it comes to MtFs the results were more controversial, among the four studies analyzed, two (50\%) showed no difference in muscle strength between post- therapy measurements and pre-therapy measurements, while the other two studies (50\%) showed a decrease in these 
measurements. It's noteworthy that the two studies in MtFs, that revealed a decrease in strength measurements analyzed grip strength. While, among the studies that found no difference, one measured lower limbs muscle strength and the other measured grip strength in adolescents, and at this mean age, the muscle strength was expected to increase. Among all four studies in FtMs, the testosterone mean levels were below $10 \mathrm{nmol} / \mathrm{L}$ (the upper limit for participation in Olympic sports) at the end.

\section{Hemoglobin/hematocrit}

Testosterone also has been linked to stimulation of erythropoiesis, increasing hemoglobin and hematocrit by stimulation of EPO and reduced ferritin and hepcidin. ${ }^{33}$ Furthermore, testosterone can directly stimulate erythropoiesis in bone marrow. ${ }^{34}$ Considering that, thrombosis risks may be a possible adverse effect, as monitored by some studies among those included in the analysis. On the other hand, as agents in the oxygen transport to tissues, increased hemoglobin/hematocrit has been shown to improve endurance performance. ${ }^{18,35}$

14 studies with FtMs analyzed the relationship of testosterone administration and hemoglobin changes, while 13 analyzed the effects on hematocrit levels. All of them revealed an increase in these measurements post-therapy, likewise the pooled estimate effect. Among the different routes of testosterone administration (gel, intramuscular and subcutaneous), the gel formulation seems to show the smallest increase in both analytes. ${ }^{56}$ This finding agrees with a meta-analysis that found a positive correlation between testosterone and higher hemoglobin and hematocrit levels in hypogonadal men. ${ }^{36}$

When it comes to MtFs, the suppression of testosterone levels by CSHT reduced hemoglobin and hematocrit levels in six of seven studies (85.7\%) that covered this analysis. Only one study found no difference in post- and pre-therapy measurements, both in hemoglobin and hematocrit. It's noteworthy that in all studies with MtFs regarding hemoglobin or hematocrit levels, the serum testosterone means at the end of the studies was below $10 \mathrm{nmol} / \mathrm{L}$, and the study that found no difference revealed the highest mean of serum testosterone concentration at the end $(6.9 \mathrm{nmol} / \mathrm{L})$.

Our meta-analysis agrees with a recent review ${ }^{37}$ that included parameters of body composition, muscle strength and hematological parameters (hemoglobin and hematocrit) in trans women, showing that these levels dropped as a consequence of hormone therapy. These confirmed findings, together with the results of FtMs and the meta-analyses in this study, promote a greater scientific basis regarding the inclusion of the transgender population in sports, especially Olympic. However, we highlight the lack of studies comparing transgender people with control groups of their target gender as a limiting factor of this analysis.

\section{CONCLUSION}

This meta-analysis provides evidence that the csht promotes changes in the strength, hematocrit, and hemoglobin measurements, both in MtFs and in FtMs. Based on the included studies, we can conclude that all of these measurements increased in FtMs after csht, while they decreased in MtFs. But considering that the studies have compared transgender individuals, who have undergone CSHT, to individuals of the same birth sex and not to individuals with the same assumed gender, it becomes difficult to infer rules on the participation of transgender people in sports. To the best of our knowledge, this is the first meta-analysis that summarizes the effects of CSHT on strength, hemoglobin, and hematocrit measurements.

\section{ACKNOWLEDGEMENTS}

The authors would like to thank the corresponding authors of studies included in this review who answered our requests, providing further information on their published data.

All authors declare no potential conflict of interest related to this article

AUTHORS' CONTRIBUTIONS: Each author made significant individual contributions to this manuscript. RMS: bibliographic search, analysis of the data and writing; RCTN: literature search and writing; and LSPLP: literature search and writing; RLN: intellectual concept, writing, analysis of the data, and revision; APSS: intellectual concept and revision.

\section{REFERENCES}

1. Lombardo MP. On the evolution of sport. Evolutionary Psychology. 2012;10(1):147470491201000101.

2. Furley P. What modern sports competitions can tell us about human nature. Perspectives on Psychological Science. 2019;14(2):138-55.

3. Zhang Y, Fu F. Strategy intervention for the evolution of fairness. PloS one. 2018;13(5):e0196524.

4. Hughes IA, Houk C, Ahmed SF, Lee PA, Society LWPE. Consensus statement on management of intersex disorders. Journal of pediatric urology. 2006;2(3):148-62.

5. Cools M, Nordenström A, Robeva R, Hall J, Westerveld P, Flück C, et al. Caring for individuals with a difference of sex development (DSD): a consensus statement. Nature Reviews Endocrinology. 2018;14(7):415-29.

6. Hembree WC, Cohen-Kettenis P, Delemarre-Van De Waal HA, Gooren LJ, Meyer III WJ, Spack NP, et al Endocrine treatment of transsexual persons: an Endocrine Society clinical practice guideline. The Journal of Clinical Endocrinology \& Metabolism. 2009;94(9):3132-54.

7. Deutsch M. Guidelines for the Primary and Gender-Affirming Care of Transgender and Gender Nonbinary People. In: UCSFTransgender Care DoFaCM, University of California San Francisco., editor. 2nd edition ed. 2016.

8. Meerwijk EL, Sevelius JM. Transgender population size in the United States: a meta-regression of population-based probability samples. American journal of public health. 2017;107(2):e1-e8.

9. Cavanagh SL, Sykes H. Transsexual bodies at the Olympics: The International Olympic Committee's policy on transsexual athletes at the 2004 Athens Summer Games. Body \& Society. 2006;12(3):75-102.

10. Vita R, Settineri S, Liotta M, Benvenga S, Trimarchi F. Changes in hormonal and metabolic parameters in transgender subjects on cross-sex hormone therapy: a cohort study. Maturitas. 2018;107:92-6.

11. Tangpricha V, den Heijer M. Oestrogen and anti-androgen therapy for transgender women. The Lancet Diabetes \& Endocrinology. 2017;5(4):291-300.

12. Storey A, Smith HK. Unique aspects of competitive weightlifting. Sports medicine. 2012;42(9):769-90.

13. Abe T, Dankel SJ, Buckner SL, Jessee MB, Mattocks KT, Mouser JG, et al. Differences in 100-m sprint performance and skeletal muscle mass between elite male and female sprinters. The Journal of sports medicine and physical fitness. 2018;59(2):304-9.

14. Vogt P, Rüst CA, Rosemann T, Lepers R, Knechtle B. Analysis of $10 \mathrm{~km}$ swimming performance of elite male and female open-water swimmers. Springerplus. 2013;2(1):1-15

15. Perkins JM, Subramanian SV, Davey Smith G, Özaltin E. Adult height, nutrition, and population health. Nutrition reviews. 2016;74(3):149-65.
16. Horton $\mathrm{R}$, Tait J. Androstenedione production and interconversion rates measured in peripheral blood and studies on the possible site of its conversion to testosterone. The Journal of clinical investigation. 1966;45(3):301-13.

17. SOUTHREN AL, GORDON GG, TOCHIMOTO S. Further study of factors affecting the metabolic clearance rate of testosterone in man. The Journal of Clinical Endocrinology \& Metabolism. 1968;28(8):1105-12.

18. Handelsman DJ, Hirschberg AL, Bermon S. Circulating testosterone as the hormonal basis of sex differences in athletic performance. Endocrine reviews. 2018;39(5):803-29.

19. IOC approves consensus with regard to athletes who have changed sex. Olympic Games. 2004.

20. Harper J HA, Jose M, Patino M, Ritzén M, Vilain E, Partner JT, Bird B\&, Riley L, Thill C. IOC Consensus Meeting on Sex Reassignment and Hyperandrogenism. Olympic Games; https://www.olympic.org/news/ ioc-approves-consensus-with-regard-to-athletes-who-have-changed-sex. https://stillmed.olympic.org/ Documents/Commissions_PDFfiles/Medical_commission/2015-1_ioc_consensus_meeting_on_sex_re assignment_and_hyperandrogenismen.pdf2015.

21. Harper J, Martinez-Patino M-J, Pigozzi F, Pitsiladis Y. Implications of a third gender for elite sports. Current sports medicine reports. 2018;17(2):42-4.

22. Camporesi S. Ethics of regulating competition for women with hyperandrogenism. Clinics in sports medicine. 2016;35(2):293-301.

23. WORLD ATHLETICS ELIGIBILITY REGULATIONS FORTRANSGENDER ATHLETES. In: IAAF, editor. http:// www.athletics.org.tw2019.

24. ARDLE M, Willian D, KATCH FI, KATCH VL. Fisiologia do exercício. Energia, Nutrição e Desempenho humano. 6a ed. Rio de Janeiro: Guanabara Koogan. 2008.

25. Genel M. Transgender athletes: how can they be accommodated? Current sports medicine reports. 2017;16(1):12-3.

26. Singh B, Singh K, Sharma N. Equality, equity and inclusion: transgender athletes' participation in competitive sports-a new era. Physical Culture and Sport Studies and Research. 2010;49(1):85-8.

27. Mauras N, Hayes V, Welch S, Rini A, Helgeson K, Dokler M, et al. Testosterone deficiency in young men: marked alterations in whole body protein kinetics, strength, and adiposity. The Journal of Clinical Endocrinology \& Metabolism. 1998;83(6):1886-92.

28. Storer TW, Magliano L, Woodhouse L, Lee ML, Dzekov C, Dzekov J, et al. Testosterone dose-dependently increases maximal voluntary strength and leg power, but does not affect fatigability or specific tension. The Journal of Clinical Endocrinology \& Metabolism. 2003;88(4):1478-85. 
29. Miller KK. Androgen deficiency: effects on body composition. Pituitary. 2009;12(2):116-24.

30. Tønnessen E, Svendsen IS, Olsen IC, Guttormsen A, Haugen T. Performance development in adolescent track and field athletes according to age, sex and sport discipline. PloS one. 2015;10(6):e0129014.

31. Ottenbacher KJ, Ottenbacher ME, Ottenbacher AJ, Acha AA, Ostir GV. Androgen treatment and muscle strength in elderly men: a meta-analysis. Journal of the American Geriatrics Society. 2006;54(11):1666-73.

32. Liu PY, Swerdloff RS, Veldhuis JD. The rationale, efficacy and safety of androgen therapy in older men: future research and current practice recommendations. The Journal of Clinical Endocrinology \& Metabolism. 2004;89(10):4789-96

33. Bachman E, Travison TG, Basaria S, Davda MN, Guo W, Li M, et al. Testosterone induces erythrocytosis via increased erythropoietin and suppressed hepcidin: evidence for a new erythropoietin/hemoglobin set point. Journals of Gerontology Series A: Biomedical Sciences and Medical Sciences. 2014;69(6):725-35.

34. Shahani S, Braga-Basaria M, Maggio M, Basaria S. Androgens and erythropoiesis: past and present. Journal of endocrinological investigation. 2009;32(8):704-16.

35. Ekblom B, Goldbarg AN, Gullbring B. Response to exercise after blood loss and reinfusion. Journal of Applied Physiology. 1972;33(2):175-80

36. Fernández-Balsells MM, Murad MH, Lane M, Lampropulos JF, Albuquerque F, Mullan RJ, et al. Adverse effects of testosterone therapy in adult men: a systematic review and meta-analysis. The Journal of Clinical Endocrinology \& Metabolism. 2010;95(6):2560-75.

37. Harper J, O'Donnell E, Khorashad BS, McDermott H, Witcomb GL. How does hormone transition in transgender women change body composition, muscle strength and haemoglobin? Systematic review with a focus on the implications for sport participation. British Journal of Sports Medicine. 2021.

38. Van Caenegem E, Wierckx K, Taes Y, Schreiner T, Vandewalle S, Toye K, et al. Body composition, bone turnover, and bone mass in trans men during testosterone treatment: 1-year follow-up data from a prospective case-controlled study (ENIGI). Eur J Endocrinol. 2015;172(2):163-71.

39. Scharff M, Wiepjes CM, Klaver M, Schreiner T, t'Sjoen G, Den Heijer M. Change in grip strength in trans people and its association with lean body mass and bone density. Endocrine connections. 2019;8(7):1020-8.

40. Van Caenegem E, Wierckx K, Taes Y, SchreinerT, Vandewalle S, Toye K, et al. Preservation of volumetric bone density and geometry in trans women during cross-sex hormonal therapy: a prospective observational study. Osteoporosis International. 2015;26(1):35-47.

41. Tack LJ, Craen M, Lapauw B, Goemaere S, Toye K, Kaufman J-M, et al. Proandrogenic and antiandrogenic progestins in transgender youth: differential effects on body composition and bone metabolism. The Journal of Clinical Endocrinology \& Metabolism. 2018;103(6):2147-56.

42. Wiik A, Lundberg TR, Rullman E, Andersson DP, Holmberg M, Mandić M, et al. Muscle strength, size, and composition following 12 months of gender-affirming treatment in transgender individuals. The Journal of Clinical Endocrinology \& Metabolism. 2020;105(3):e805-e13.

43. Mueller A, Haeberle L, Zollver $\mathrm{H}$, Claassen T, Kronawitter D, Oppelt PG, et al. Effects of intramuscular testosterone undecanoate on body composition and bone mineral density in female-to-male transsexuals. The journal of sexual medicine. 2010;7(9):3190-8.

44. Jacobeit JW, Gooren L, Schulte HM. Endocrinology: long-acting intramuscular testosterone undecanoate for treatment of female-to-male transgender individuals. The journal of sexual medicine. 2007;4(5):1479-84

45. Fernandez J, Tannock L. Metabolic effects of hormone therapy in transgender patients. Endocrine Practice. 2016;22(4):383-8.

46. Jacobeit J, Gooren L, Schulte H. Safety aspects of 36 months of administration of long-acting intramuscular testosterone undecanoate for treatment of female-to-male transgender individuals. European journal of endocrinology. 2009;161(5):795.

47. Abdala R, Nagelberg A, Silveira F, Otero P, Mormandi E. Short-term safety profile of cross-hormonal therapy in trans-male subjects. Medicina. 2018;78(6):399-402.

48. Tack L, Craen M, Dhondt K, Bossche HV, Laridaen J, Cools M. Consecutive lynestrenol and cross-sex hormone treatment in biological female adolescents with gender dysphoria: a retrospective analysis. Biology of sex Differences. 2016;7(1):1-11.

49. Stoffers IE, de Vries MC, Hannema SE. Physical changes, laboratory parameters, and bone minera density during testosterone treatment in adolescents with gender dysphoria. The journal of sexual medicine. 2019;16(9):1459-68

50. 5Jarin J, Pine-Twaddell E, Trotman G, Stevens J, Conard LA, Tefera E, et al. Cross-sex hormones and metabolic parameters in adolescents with gender dysphoria. Pediatrics. 2017;139(5).

51. Wierckx K, Van Caenegem E, Schreiner T, Haraldsen I, Fisher A, Toye K, et al. Cross-sex hormone therapy in trans persons is safe and effective at short-time follow-up: results from the European network for the investigation of gender incongruence. The journal of sexual medicine. 2014;11(8):1999-2011.

52. Olson-Kennedy J, Okonta V, Clark LF, Belzer M. Physiologic response to gender-affirming hormones among transgender youth. Journal of Adolescent Health. 2018;62(4):397-401.

53. SoRelle JA, Jiao R, Gao E, Veazey J, Frame I, Quinn AM, et al. Impact of hormone therapy on laboratory values in transgender patients. Clinical chemistry. 2019;65(1):170-9.

54. Mueller A, Kiesewetter F, Binder H, Beckmann MW, Dittrich R. Long-term administration of testosterone undecanoate every 3 months for testosterone supplementation in female-to-male transsexuals. The Journal of Clinical Endocrinology \& Metabolism. 2007;92(9):3470-5.

55. Chandra P, Basra SS, Chen TC, Tangpricha V. Alterations in lipids and adipocyte hormones in female-to-male transsexuals. International journal of endocrinology. 2010;2010.

56. Pelusi C, Costantino A, Martelli V, Lambertini M, Bazzocchi A, Ponti F, et al. Effects of three different testosterone formulations in female-to-male transsexual persons. The journal of sexual medicine. 2014;11(12):3002-11.

57. Tack LJ, Heyse R, Craen M, Dhondt K, Bossche HV, Laridaen J, et al. Consecutive cyproterone acetate and estradiol treatment in late-pubertal transgender female adolescents. The journal of sexual medicine. 2017;14(5):747-57. 